Artikel Riset

DOI : 10.33751/jf.v8i1.1169
Fitofarmaka Jurnal Ilmiah Farmasi

Vol. 8, No.1, Juni $2018: 32-42$

p-ISSN : 2087-9164 e-ISSN : 2622-755X

\title{
EFEKTIVITAS SALEP EKSTRAK ETANOL 70\% DAUN PANDAN WANGI TERHADAP PENYEMBUHAN LUKA BAKAR PADA MENCIT PUTIH JANTAN
}

\author{
Rini Wijayantini*, Ratna Cahyaningsih, Andinny Nur Permatasari \\ Program Studi Farmasi, FMIPA, Universitas Pakuan, PO Box 452 Bogor 16143, \\ West Java, Indonesia \\ *E-mail: riniwijayantini@ymail.com
}

Diterima : 7 Januari 2018

Direvisi : 11 Januari 2018

Disetujui : 16 Maret 2018

\begin{abstract}
ABSTRAK
Luka bakar adalah kerusakan jaringan yang disebabkan kontak dengan sumber panas. Penelitian ini bertujuan untuk mengetahui pengaruh salep ekstrak etanol $70 \%$ daun pandan wangi terhadap penyembuhan luka bakar pada mencit putih jantan. Hewan coba yang digunakan adalah 28 ekor mencit putih jantan, berumur 2-3 bulan dengan bobot 25-40 g. Penelitian ini menggunakan Rancangan Acak Lengkap (RAL) pola faktorial dengan 7 kelompok perlakuan, masing-masing perlakuan terdiri dari 4 ekor mencit. Luka bakar derajat II dibuat pada punggung mencit dengan menempelkan logam berukuran $1 \mathrm{~cm}$ yang telah dipanaskan selama 5 menit pada suhu $98^{0} \mathrm{C}$ dan ditempelkan selama 10 detik. Perawatan dilakukan sehari sekali selama 16 hari terhadap kelompok P1 (Kelompok yang dilukai dan tanpa diberikan perlakuan apapun), P2 (hanya diberi basis salep), P3 (hanya diberi ekstrak 5\% tanpa basis), P4 (diberi bioplacenton sebagai kontrol positif), P5 (diberi salep ekstrak 5\%), P6 (salep ekstrak 7,5\%) dan P7 (Salep Ekstrak 10\%). Hasil penelitian menunjukkan bahwa perlakuan dengan salep ekstrak 5\% (P5), 7,5\% (P6) dan 10\% (P7) memberikan pengaruh positif terhadap penyembuhan luka bakar pada mencit. Perlakuan salep ekstrak 10\% (P7) paling optimal dalam mempercepat penyembuhan luka bakar dilihat dari jangka waktu penyembuhan pada hari ke 13 luka sudah sembuh dibandingkan perlakuan pada kelompok lainnya. Dapat disimpulkan bahwa salep ekstrak pandanwangi 10\% memiliki potensi sebagai obat luka bakar.
\end{abstract}

Kata kunci : Daun pandan wangi, luka bakar, salep luka bakar

\section{THE EFFECTIVITY OF 70\% PANDAN LEAVES ETHANOL EXTRACT OINTMENT ON BURN WOUND HEALING IN WHITE MALE MICE}

\begin{abstract}
Burn is a type of damage on skins tissue caused by contact with high temperature. This study aimed to determine the effect of $70 \%$ ethanol extract oinment of pandan leaves on burn wound healing. The factorial completely randomized design (CRD) using 28 white male mice weighed 25-40, age between 2-3 months was conducted in the study. The mice ware divided into 7 treatment groups, each group consisting of 4 replicates. Second-degree burn was made on the back of the mice by placing a $1 \mathrm{~cm}^{2}$ hot iron plate that has been heated for 5 minutes at $98^{0} \mathrm{C}$ for 10
\end{abstract}


seconds. Treatment was performed once daily for 16 days consist of P1 (the injured group without any treatment), P2 (treated with ointment without plant extract), P3 (treated with 5\% extract without ointment), P4 (treated with bioplancenton as positive control), P5 (treated with ointment extract 5\% ), P6 (treated with ointment extract 7.5\%) and P7 (treated with ointment extract 10\%). The results showed that 5\% (P5), 7.5\% (P6) and $10 \%(\mathrm{P} 7)$ of ointment extracts have the positive effect on wound healing in mice. The ointment extract 10\% (P7) found to be the optimal dose in accelerating the healing of burns. The application of ointment extract $10 \%$ has healed the burns on day 13, faster compared to other treatment groups.

Key words : Pandanus amaryllifolius, burn healing, burn ointment

\section{PENDAHULUAN}

Prevalensi luka bakar pada tahun 2013 di Indonesia sebesar 0,7\% dan telah mengalami penurunan sebesar $1,5 \%$ dibandingkan pada tahun 2008 (2,2\%). Provinsi dengan prevalensi tertinggi adalah Papua (2\%) dan Bangka Belitung (1,4\%) (Balitbang, 2013). Berdasarkan data rekam medis RSUP Haji Adam Malik Medan, terdapat 353 kasus luka bakar pada tahun 2011-2014 dengan penyebab terbanyak adalah flame burn injury (174 kasus, 50,4\%) (Maulana, 2014).

Perawatan luka bakar yang kurang tepat akan menyebabkan komplikasi, infeksi dan pendarahan. Hal tersebut akan memperpanjang lama waktu penyembuhan serta menambah biaya perawatan. Luka bakar yang tidak segera diobati akan didiami oleh bakteri patogen dengan cepat, mengalami eksudasi dengan perembasan sejumlah besar air, protein serta elektrolit dan sering memerlukan pencangkokan kulit dari bagian tubuh yang lain untuk menghasilkan penutupan luka yang permanen (Arif, 2011).

Penggunaan obat tradisional dapat dijadikan solusi alternatif penanganan luka bakar. Salah satu tanaman yang dapat digunakan yaitu daun pandan wangi. Selain berupa tanaman lokal yang mudah ditanam, persebarannya pun cukup banyak di Indonesia yang berpotensi, serta ekonomis.

Pada penelitian sebelumnya telah dilakukan pengujian terhadap ekstrak kloroform dari spesies Pandanus fascicularis Lamk terhadap aktivitas penyembuhan luka eksisi pada tikus albino galur swiss dalam sediaan gel dan salep dengan konsentrasi 5\%, 7,5\%, 10\%, kontrol dan pembanding. Hasilnya menunjukkan bahwa ekstrak kloroform konsentrasi $10 \%$ dalam kedua bentuk sediaan tersebut memiliki kemampuan penyembuhan luka yang lebih cepat dibandingkan dengan dosis lain dan setara dengan produk komersial seperti Neosporin dan Betadine (Panda et al., 2009).

Berdasarkan penelitian diatas, maka penulis melanjutkan penelitian efektivitas ekstrak dan salep daun pandan wangi dengan ekstraksi pelarut etanol $70 \%$ dan basis salep yang berbeda dari penelitian sebelumnya untuk penyembuhan luka bakar pada mencit putih jantan. 


\section{METODE PENELITIAN}

\section{Bahan dan Alat.}

Penelitian ini dilaksanakan selama

2 (dua) bulan mulai dari bulan Maret sampai bulan April 2017 di Laboratorium Farmasi Fakultas Matematika dan Ilmu Pengetahuan Alam Universitas Pakuan, Bogor.

Bahan yang digunakan adalah serbuk simplisia daun pandan wangi, vaselin, paraffin cair, Bioplacenton ${ }^{\circledR}$, krim anastesi, akuades, etanol 70\%, kapas, mencit putih jantan dengan umur 2-3 bulan dan bobot 25-40 g, serta pelet BR-12.

Alat yang digunakan adalah vaccum dry $\left(\right.$ Ogawa $\left.^{\circledR}\right)$, oven $\left(\right.$ Memmer $^{()}$, moisture balance (Ohauss ${ }^{\circledR}$ ), tanur $\left(\mathrm{Ney}^{\circledR}\right)$, blender, hot plate, pencukur bulu, lempeng logam bulat, timbangan hewan, lemari pendingin, kandang hewan coba beserta kelengkapan pemberian pakan dan alat-alat gelas.

\section{Penyiapan Simplisia}

Pandanus amaryllifolius Roxb atau tanaman pandan wangi diperoleh dari daerah Cibeureum, Bogor Selatan. Sebelum dilakukan penelitian, tanaman terlebih dahulu dideterminasi di Herbarium Bogoriense Bidang Botani Pusat Penelitian Biologi-LIPI Bogor untuk memastikan kebenaran simplisia.

Sebanyak $4 \mathrm{~kg}$ daun pandan wangi dipilih yang sesuai dengan kriteria yaitu daun yang berwarna hijau tua, tidak rusak dan tidak busuk. Daun dicuci hingga bersih dibawah air yang mengalir, kemudian diangin-anginkan hingga sisa air pencuci kering tetapi daun tidak layu.
Setelah kering, daun dipotong kecil-kecil ukuran $\pm 1 \mathrm{~cm}$ dan dimasukkan ke dalam oven simplisia selama 24 jam. Setelah kering daun dihaluskan dengan cara diblender sampai halus kemudian diayak menggunakan mesh 60 lalu ditimbang untuk mendapatkan berat akhir simplisia.

\section{Pembuatan Ekstrak Kering}

Ekstrak kering daun pandan dibuat dengan cara merendam $250 \mathrm{~g}$ serbuk simplisia menggunakan alat maserator atau toples berwarna gelap menggunakan cairan penyari etanol $70 \%$ sebanyak 10x bobot bahan, simplisia yang sudah direndam diaduk selama 30 menit lalu didiamkan selama 24 jam, kemudian saring filtratnya. Remaserasi dilakukan selama 3 hari. Hasil filtrat diendapkan selama 2 hari lalu diuapkan dalam vacuum dry.

\section{Identifikasi Fitokimia Sampel}

Dilakukan uji fitokimia baik pada serbuk simplisia maupun ekstrak, meliputi identifikasi alkaloid, flavonoid, saponin, tanin dan polifenol.

\section{Pengujian Mutu Ekstrak}

Pengujian mutu ekstrak daun pandan wangi meliputi penetapan kadar abu total dengan menggunakan metode gravimetri serta penetapan kadar air menggunakan alat moisture balance.

\section{Pembuatan Sediaan Salep}

Salep dibuat ke dalam tiga formulasi dengan variasi dosis ekstrak etanol daun pandan wangi pada konsentrasi 5\%, 7,5\% dan 10\%. Adapun formulanya dapat dilihat pada Tabel 1 . 
Tabel 1. Formulasi Sediaan Salep Ekstrak Etanol Daun Pandan Wangi

\begin{tabular}{lllll}
\hline No. & Nama Bahan & F I & F II & F III \\
\hline 1 & Ekstrak Etanol Daun Pandan (\%) & 5 & 7,5 & 10 \\
2 & Paraffin Cair (\%) & 8,5 & 8,5 & 8,5 \\
3 & Vaselin kuning (\%) dalam 25 g & ad 100 & ad 100 & ad 100 \\
\hline
\end{tabular}

Keterangan :

F I : Formula salep ekstrak etanol daun pandan wangi konsentrasi 5\%

F II : Formula salep ekstrak etanol daun pandan wangi konsentrasi 7,5\%

F III : Formula salep ekstrak etanol daun pandan wangi konsentrasi 10\%

\section{Evaluasi Sediaan Salep}

Evaluasi sediaan salep meliputi uji organoleptis, uji daya sebar dan uji $\mathrm{pH}$ dilakukan menggunakan metoda Maulana dan Nining (2015).

a) Uji Organoleptis

Meliputi pengamatan terhadap bentuk, warna dan bau dari sediaan yang telah dibuat.

b) Uji Daya Sebar

Sebanyak 0,5 g salep diletakkan dalam kaca bulat, kaca lainnya diletakkan ditasnya dan dibiarkan selama 1 menit. Setelah itu, ditambahkan $150 \mathrm{~g}$ beban didiamkan 1 menit dan diukur diameter konstan

c) Uji pH

Pengujian $\mathrm{pH}$ dilakukan dengan menggunakan kertas $\mathrm{pH}$ universal yang dicelupkan ke dalam sampel salep yang telah diencerkan, lalu dicocokkan dengan standar $\mathrm{pH}$ universal.

\section{Persiapan Hewan Uji}

Sebanyak 28 ekor mencit putih jantan, berumur 2-3 bulan dengan bobot 25-40 g disiapkan dan dibagi menjadi 7 kelompok perlakuan. Semua hewan coba diaklimatisasi selama 7 hari. Selama aklimatisasi dan penelitian mencit diberi pakan pelet BR-12 dan minum secara $a d$ libitum dan ditempatkan di bak plastik terpisah dengan ukuran $30 \mathrm{~cm}$ x $20 \mathrm{~cm} \mathrm{x}$ $12 \mathrm{~cm}$.

\section{Tahap Perlakuan}

1) Sehari sebelum pembuatan luka, bulu di sekitar punggung dicukur hingga licin dan kulit didesinfektasi.

2) Pada saat pembuatan luka terlebih dahulu dilakukan anastesi pada kulit mencit dengan menggunakan krim anastesi lokal yang dioleskan ke kulit dan ditunggu selama 30 menit.

3) Perlukaan dilakukan pada punggung mencit dengan cara menempelkan logam berbentuk lingkaran dengan diameter $1 \mathrm{~cm}$ selama 10 detik yang sebelumnya telah dipanaskan didalam air bersuhu $98^{\circ} \mathrm{C}$ selama 5 menit.

4) Perlakuan pengobatan dilakukan terhadap masing-masing kelompok tikus 5 menit sejak pembuatan luka sesuai matriks penelitian (Tabel 2) dengan cara mengoleskan salep untuk pertama kalinya disekitar tempat luka menggunakan batang pengaduk. Dilakukan pengamatan dan pengolesan salep 1 hari sekali pada pagi hari (selama 16 hari). 
Tabel 2. Kelompok Perlakuan Dosis Salep Ekstrak

\begin{tabular}{cccc}
\hline Perlakuan & Kelompok & Perlakuan & $\begin{array}{c}\text { Jumlah } \\
\text { Mencit (ekor) }\end{array}$ \\
\hline P1 & Kontrol & Kelompok yang dilukai tanpa diberi \\
pormal & perlakuan & 4 \\
P2 & Kontrol & Kelompok yang dilukai dan hanya diberi & 4 \\
& Negatif & basis salep \\
P3 & Kontrol & $\begin{array}{c}\text { Kelompok yang dilukai dan diberi } \\
\text { ekstrak 5\% tanpa basis salep }\end{array}$ & 4 \\
P4 & Standar & $\begin{array}{c}\text { Kelompok yang dilukai dan diberi } \\
\text { Bioplacenton }\end{array}$ & 4 \\
P5 & Salep Ekstrak & $\begin{array}{c}\text { Kelompok yang dilukai dan diberi } \\
\text { sediaan salep ekstrak 5\% }\end{array}$ & 4 \\
P6 & Salep Ekstrak & Kelompok yang dilukai dan diberi \\
& $7,5 \%$ & sediaan salep ekstrak 7,5\% & 4 \\
P7 & Salep Ekstrak & Kelompok yang dilukai dan diberi \\
& $10 \%$ & sediaan salep ekstrak 10\% & 4 \\
\hline
\end{tabular}

\section{Penentuan Persentase Penyembuhan}

\section{Luka}

Persentase penyembuhan luka bakar diukur dari berkurangnya diameter luka bakar pada tikus uji. Pengukuran diameter luka dilakukan menggunakan alat jangka sorong dengan metode Morton yaitu mengukur empat diameter luka secara tetap dibatasi sampai hari ke16, kemudian dihitung nilai rata-rata diameter tiap pengukurannya. Perawatan terhadap luka bakar pada hewan uji dilakukan setiap hari, sedangkan pengukuran dan pengambilan data diameter luka pada hewan uji dilakukan tiap 3 hari sekali (hari ke 1, 4, 7, 10, 13 dan 16) sampai maksimal hari ke-16. Adapun penentuan pengukuran diameter luka bakar dapat dilihat pada Gambar 1 .

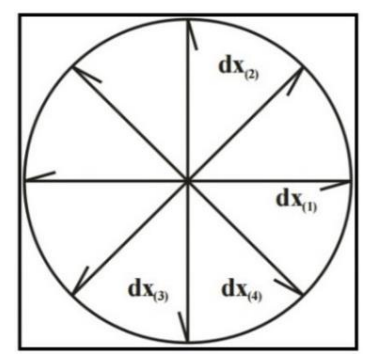

Gambar 1. Pengukuran 4 Arah Diameter Luka (Silalahi \& Chemayanti, 2015)

Diameter luka bakar yang diperoleh dihitung menggunakan rumus :

$D x=\frac{\mathrm{dx}_{1}+\mathrm{dx}_{2}+\mathrm{dx}_{3}+\mathrm{dx}_{4}}{4}$

Keterangan :

$\mathrm{dx}_{(1)}$ : Diameter horizontal

$\mathrm{dx}_{(2)}$ : Diameter vertikal

$\mathrm{dx}_{(3)}$ dan $\mathrm{dx}_{(4)}$ : Diameter diagonal

Sedangkan persentase penyembuhan luka diperhitungkan dengan rumus berikut : 
$\mathrm{L}=\frac{(\mathrm{D} 1)^{2}-(\mathrm{D} 2)^{2}}{(\mathrm{D} 1)^{2}} \times 100 \%$

Keterangan :

$\mathrm{D}_{1}=$ diameter luka sehari setelah luka dibuat

$\mathrm{D}_{2}=$ diameter luka pada hari pengamatan

\section{Analisis Statistik}

Data yang dihasilkan dari penelitian ini dianalisis dengan metode sidik ragam Rancangan Acak Lengkap Pola Faktorial (Faktorial RAL). Faktorial RAL dipilih sebagai metode statistik karena pada penelitian ini bahan yang digunakan homogen dan penelitian dilakukan di dalam laboratorium dengan lingkungan yang relatif homogen. Parameter yang diamati pada penelitian ini ada dua mcam yaitu perbedaan dosis ekstrak pandan wangi dan perbedaan lama waktu penyembuhan luka bakar, sehingga rancangan penelitian yang digunakan adalah rancangan faktorial.

\section{HASIL DAN PEMBAHASAN \\ Determinasi Tanaman}

Hasil determinasi tanaman yang dilakukan di Herbarium Bogoriense Bidang Botani Pusat Penelitian BiologiLIPI Bogor diketahui bahwa tanaman yang digunakan merupakan tanaman dari spesies Pandanus amaryllifolius Roxb, termasuk genus pandanus dari suku Pandanaceae.

\section{Hasil Identifikasi Fitokimia Sampel}

Berdasarkan hasil penapisan fitokimia pada simplisia dan ekstrak daun pandan wangi menunjukkan hasil yang sama, yaitu adanya kandungan golongan senyawa alkaloid, flavonoid, saponin, tanin dan polifenol. Hasil identifikasi fitokimia sampel dapat dilihat pada Tabel 3.

Tabel 3. Hasil Skrining Fitokimia Simplisia dan Ekstrak

\begin{tabular}{clcc}
\hline No & $\begin{array}{l}\text { Golongan } \\
\text { Senyawa }\end{array}$ & Simplisia & Ekstrak \\
\hline 1 & Alkaloid & $\sqrt{ }$ & $\sqrt{ }$ \\
2 & Flavonoid & $\sqrt{ }$ & $\sqrt{ }$ \\
3 & Saponin & $\sqrt{ }$ & $\sqrt{ }$ \\
4 & Tanin dan & $\sqrt{ }$ & $\sqrt{ }$ \\
& Polifenol & & \\
\hline
\end{tabular}

\section{Penetapan Mutu Sampel}

Penetapan mutu sampel terdiri atas uji kadar air dan kadar abu, hasil menunjukkan bahwa baik kadar air maupun kadar abu sampel daun pandan wangi keduanya telah memenuhi persyaratan sebagai sampel bahan penelitian. Hasil penetapan mutu sampel dapat dilihat pada Tabel 4.

Tabel 4. Hasil Penetapan Mutu Sampel

\begin{tabular}{lcccc}
\hline Jenis Bahan & Kadar Air & Persyaratan & Kadar Abu & Persyaratan \\
\hline Serbuk Simplisia Daun & $8,21 \%$ & $7,88-9,14 \%$ & $3,41 \%$ & $\leq 9 \%$ \\
Pandan Wangi & & & & \\
Ekstrak Etanol Daun & $1,62 \%$ & $<5 \%$ & $4,16 \%$ & \\
Pandan Wangi & & & & \\
\hline
\end{tabular}




\section{Evaluasi Sediaan Salep}

Evaluasi salep ekstrak etanol daun pandan wangi meliputi uji organoleptik, uji daya sebar dan uji pH. Pemeriksaan organoleptis dilakukan secara visual dengan mengamati tampilan fisik, warna dan juga bau dari ketiga sediaan. Salep yang dihasilkan memiliki tampilan fisik warna kehijauan merupakan hasil warna dari adanya kandungan ekstrak daun pandan wangi semi padat yang merupakan karakteristik dari salep itu sendiri. Warna kehijauan. Hal ini terlihat dari perubahan warna basis salep yang asalnya berwarna kuning menjadi kehijauan. Semakin tinggi kadar konsentrasi ekstrak yang terkandung maka warnanya menjadi lebih pekat seperti kecoklatan. Aroma yang dihasilkan dari ketiga sediaan yaitu menghasilkan aroma khas pandan yang kuat. Bentuk sediaan salep ekstrak etanol daun pandan wangi dapat dilihat pada Gambar 2.

Berdasarkan hasil pengujian $\mathrm{pH}$ diketahui bahwa ketiga sediaan salep menunjukkan $\mathrm{pH}$ 5, hal tersebut memenuhi persyaratan $\mathrm{pH}$ sediaan topikal yaitu antara 4,5-6,5 (Tranggono dan Fatma, 2007).

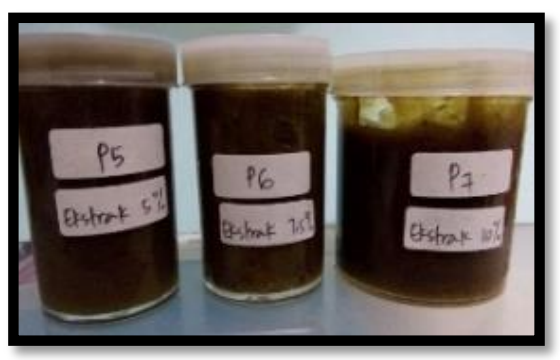

Gambar 2. Sediaan salep ekstrak

Hasil uji daya sebar, menunjukkan diameter penyebaran salep ekstrak 5\%; $7,5 \%$ dan $10 \%$ secara berturut-turut adalah 5,69 cm; 5,39 $\mathrm{cm}$ dan $5,15 \mathrm{~cm}$. Persyaratan daya sebar untuk sediaan topikal yaitu sekitar 5-7 cm (Martin et al.,1990), maka berdasarkan hasil uji daya sebar pada sediaan dapat dinyatakan bahwa ketiga sediaan sudah memenuhi syarat daya sebar yang baik.

Secara keseluruhan hasil evaluasi sediaan salep ekstrak etanol daun pandan wangi untuk ketiga formula dapat dilihat pada Tabel 5.

Tabel 5. Hasil Evaluasi Sediaan Salep Ekstrak

\begin{tabular}{llccc}
\hline 'No. & Parameter Pengujian & \multicolumn{3}{c}{ Hasil Pengamatan } \\
\cline { 3 - 5 } & & Ekstrak 5\% & Ekstrak 7,5\% & Ekstrak 10\% \\
\hline 1. & Organoleptis & Semi padat & Semi padat & Semi padat \\
& • Penampilan & Hijau lumut & Hijau lumut & Hijau kecoklatan \\
& • Warna & Khas pandan & Khas pandan & Khas pandan \\
& • Bau & $5,69 \mathrm{~cm}$ & $5,39 \mathrm{~cm}$ & $5,15 \mathrm{~cm}$ \\
2. & Uji Daya Sebar & 5 & 5 & 5 \\
3. & Uji Ph & & & \\
\hline
\end{tabular}




\section{Hasil Uji Terhadap Hewan Coba}

Selama 16 hari, diameter luka pada mencit diukur menggunakan jangka sorong dengan pengukuran metode Morton dengan interval 3 hari sekali yaitu pada hari ke 1,4,7,10,13 dan 16 .
Data diameter luka kemudian dicari rata-rata tiap pengukurannya lalu dihitung persentase kesembuhannya. Hasil pengamatan rata-rata persentase penyembuhan luka dapat dilihat pada Tabel 6.

Tabel 6. Hasil Rata-rata Persentase Penyembuhan Luka Bakar Pada Mencit

\begin{tabular}{|c|c|c|c|c|c|c|}
\hline \multirow{2}{*}{$\begin{array}{l}\text { Kelompok } \\
\text { Perlakuan }\end{array}$} & \multicolumn{5}{|c|}{ Hari ke- (dalam \%) } & \multirow[t]{2}{*}{$\bar{x}$} \\
\hline & 4 & 7 & 10 & 13 & 16 & \\
\hline P1 & 13.46 & 29.91 & 35.26 & 52.22 & 94.58 & 45.08 \\
\hline $\mathrm{P} 2$ & 14.60 & 36.98 & 51.52 & 82.78 & 95.73 & 56.32 \\
\hline P3 & 31.55 & 50.45 & 73.69 & 94.59 & 100 & 70.05 \\
\hline $\mathrm{P} 4$ & 29.74 & 40.22 & 62.68 & 88.90 & 100 & 64.31 \\
\hline P5 & 36.88 & 52.13 & 76.25 & 95.48 & 100 & 72.15 \\
\hline P6 & 38.52 & 53.58 & 78.57 & 95.78 & 100 & 73.46 \\
\hline P7 & 42.58 & 56.28 & 82.17 & 100 & 100 & 76.20 \\
\hline $\bar{x}$ & 29.62 & 45.77 & 65.73 & 86.74 & 98.62 & \\
\hline
\end{tabular}

Keterangan : Nilai rata-rata yang diikuti huruf superskrip yang sama pada kolom dan lajur yang sama, menunjukkan pengaruh yang tidak berbeda nyata $(\mathrm{p}>0.05)$.

Hasil penelitian mengenai penyembuhan luka bakar pada mencit efektivitas salep ekstrak etanol daun dapat dilihat dalam bentuk grafik pada pandan wangi terhadap persentase Gambar 3.

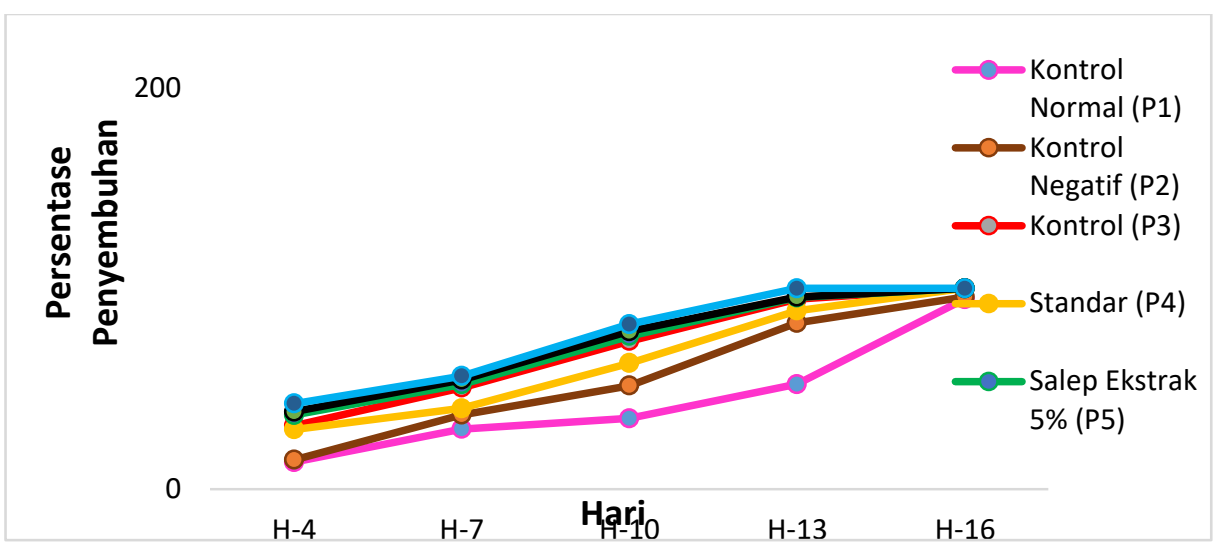

Gambar 3. Grafik Persentase Penyembuhan Luka Bakar

Persentase penyembuhan luka bakar menunjukkan data kesembuhan yang paling tinggi didapat dari perlakuan menggunakan salep ekstrak $10 \% \quad(\mathrm{P} 7)$, dimana persentase kesembuhannya mencapai $100 \%$ pada 
hari ke-13, disusul oleh kelompok P6 $(95,78 \%)$ dan P5 $(95,48 \%)$. Hal ini menandakan perlakuan salep dengan penambahan ekstrak daun pandan jauh lebih baik dalam mempercepat penyembuhan luka bakar dibandingkan produk Bioplacenton (P4) sebesar 88,90 $\%$ selama 13 hari. Adapun gambaran penyembuhan luka bakar antar kelompok perlakuan pada hari ke-13 dapat dilihat pada Gambar 4.

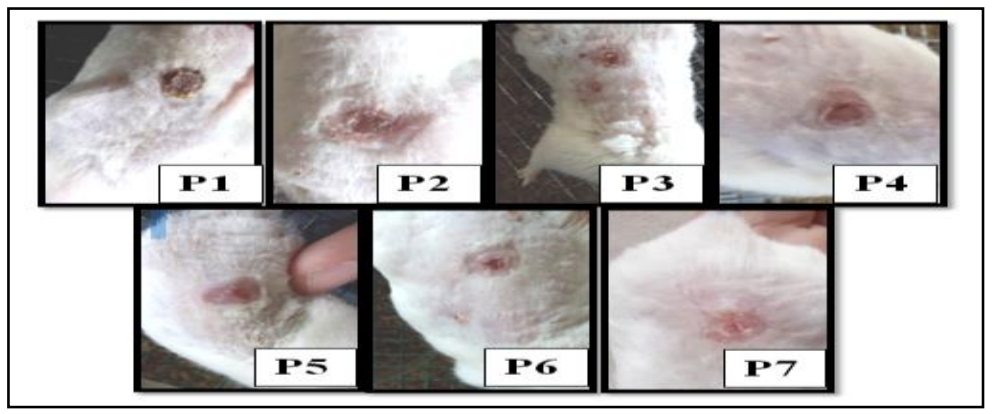

Gambar 4. Penyembuhan luka bakar antar kelompok perlakuan

\section{Mekanisme Penyembuhan Luka}

Aktivitas ekstrak etanol daun pandan wangi dalam menyembuhkan luka diduga disebabkan oleh kandungan berbagai senyawa metabolit dalam daun pandan wangi. Hasil skrining fitokimia ekstrak etanol daun pandan wangi memberikan hasil positif pada identifikasi senyawa saponin, flavonoid, alkaloid, tanin dan polifenol.

Mekanisme saponin terhadap luka yaitu bekerja sebagai antimikroba. Saponin memiliki kemampuan sebagai pembersih dan antiseptik yang berfungsi membunuh atau mencegah pertumbuhan mikroorganisme yang biasa timbul pada luka sehingga luka tidak mengalami infeksi yang berat (Harborne, 1997). Saponin juga memicu pembentukan kolagen dimana semakin banyak terdapat kolagen akan semakin cepat menarik fibroblast ke tepi luka sehingga fibroblast akan mengalami perubahan fenotif menjadi miofibroblast yang mempercepat proses kontraksi luka sehingga ukuran luka cepat berkurang (Schwartz et al., 2000).

Menurut Robinson

kandungan flavonoid, tanin, dan alkaloid pada tumbuhan membantu mempercepat proses penyembuhan luka. Kandungan flavonoid daun pandan juga turut mempercepat proses penyembuhan luka melalui mekanisme penghambatan proses inflamasi. Flavonoid menghambat inflamasi luka melalui beberapa cara yaitu dengan menghambat permeabilitas kapiler, menghambat metabolisme asam arakidonat sehingga produksi prostaglandin berkurang, menghambat sekresi enzim lisosom yang merupakan mediator inflamasi dan menghambat mediator proliferasi sel radang pada luka.

Kandungan tanin yang ada dalam ekstrak etanol daun pandan wangi berguna sebagai astringen yang menyebabkan penciutan pori-pori kulit, menghentikan eksudat dan pendarahan 
ringan, sehingga mampu menutupi luka dan mencegah pendarahan yang biasa timbul pada luka.

Mekanisme alkaloid terhadap penyembuhan luka diduga dengan cara mengganggu komponen penyusun peptidoglikan pada sel bakteri, sehingga lapisan dinding sel tidak terbentuk secara utuh dan menyebabkan kematian sel tersebut.

\section{KESIMPULAN}

1. Salep ekstrak etanol daun pandan wangi dapat membantu proses penyembuhan luka bakar pada kulit mencit.

2. Kelompok perlakuan sediaan salep ekstrak 5\% (P5), ekstrak 7,5\% (P6) dan ekstrak 10\% (P7) memberikan efektivitas paling baik terhadap waktu penyembuhan luka bakar dibanding dengan kelompok standar (Bioplacenton) (P4).

\section{SARAN}

1. Perlu dilakukan uji lanjut pada ekstrak etanol daun pandan wangi terhadap waktu kesembuhan luka bakar pada hewan uji yang terinfeksi Staphylococcus aureus.

2. Perlu dilakukan uji lanjut pengaruh pemberian ekstrak etanol daun pandan wangi terhadap waktu kesembuhan luka bakar dengan penampang gambaran hispatologis.

\section{UCAPAN TERIMA KASIH}

Terima kasih kepada Direktorat Jenderal Pendidikan tinggi yang telah membiayai penelitian ini, kepada ibu
Yulianita M.Farm selaku dosen pembimbing serta berbagai pihak yang tidak bisa disebutkan satu persatu yang telah membantu dalam penelitian ini.

\section{REFERENSI}

Arif M. \& S. Kumala. 2011. Asuhan Keperawatan Gangguan Sistem Integumen. Salemba Medika. Jakarta.

Balitbang, Kemenkes RI. 2013. Riset Kesehatan Dasar; RISKERDAS. Badan Penelitian dan Pengembangan Kesehatan, Kemenkes RI. Jakarta.

Harborne, J.B. 1997. Metode Fitokimia :Penuntun Cara Modern Menganalisis Tumbuhan. ITB Press. Bandung.

Maulana, R.A. 2014. Faktor resiko yang berperan pada mortalitas penderita luka bakar rawat inap di RSUPH Adam Malik Medan. Tesis. Fakultas Kedokteran Universitas Sumatera Utara. Medan.

Maulina, L \& S. Nining. 2015. Formulasi gel ekstrak etanol kulit buah manggis (Garcinia mangostana) dengan variasi gelling agent sebagai sediaan luka bakar. Pharmaciana. 5(1): 43-52.

Martin, A., S. James S. \& C. Arthur. 1990. Farmasi Fisik : DasarDasar Kimia Fisik dalam Ilmu Farmaseutik 1 (Edisi 3). UI Press. Jakarta.

Panda, P., S.N. Siva, M. Abinash, P.P Durga \& K.P Prasana 2009. Formulation and evaluation of topical dosage form of Pandanus 
Efektivitas Salep.....(Rini Wijayantini, dkk.)

fascicularis Lamk. and their wound healing activity. J. Pharm. Res. 2(4): 630-635.

Robinson, T. 1995. Kandungan Organik Tumbuhan Tingkat Tinggi. Penerjemah: K. Padmawinata. Penerbit ITB. Bandung.

Schwartz S. \& S. Spencer. 2000. Intisari Prinsip-Prinsip Ilmu Bedah. EGC. Jakarta.
Silalahi, J. \& S. Chemayanti. 2015. Burn wound healing activity of virgin coconut oil. Int. J. Pharm. Tech. Res. 8(1): 67-73.

Tranggono, R.I. \& L. Fatma. 2007. Buku Pegangan Ilmu Pengetahuan Kosmetik. PT Gramedia Pustaka Utama. Jakarta. 